\title{
3. QUATERNARY PLATE CONVERGENCE RATES AT THE NEW HEBRIDES ISLAND ARC FROM THE CHRONOSTRATIGRAPHY OF BOUGAINVILLE GUYOT (SITE 831) ${ }^{1}$
}

\author{
Frederick W. Taylor, ${ }^{2}$ Terrence M. Quinn, ${ }^{3}$ Christina D. Gallup, ${ }^{4}$ and R. Lawrence Edwards ${ }^{4}$
}

\begin{abstract}
We have determined convergence rates of the Australia plate with the New Hebrides Island Arc using the chronostratigraphy of Bougainville Guyot, drilled at Site 831, Ocean Drilling Program Leg 134. The convergence rate at the New Hebrides Island Arc is the vectorial sum of convergence rates between the Australia and Pacific plates ( $8.8 \mathrm{~cm} / \mathrm{yr}$ at Espiritu Santo Island) and the opening rate of the North Fiji Basin. We assume that the relative motion of the Australia and Pacific plates is unchanging on the $1.5 \mathrm{~m}$.y. time scale and that any changes of rate occurred in the North Fiji Basin. Convergence rates can be calculated because we know the distances at which carbonate sedimentation would cease and resume as the Bougainville Guyot emerged and submerged during its crossing of the outer rise flexure west of the New Hebrides Island Arc. From 1.42 to 0.393 Ma, Bougainville Guyot was subaerially exposed as it moved approximately $177 \mathrm{~km}$ across the outer rise and no sediment was deposited. The mean convergence rate during this time interval was $17.2 \pm 7 \mathrm{~cm} / \mathrm{yr}$, as determined from strontium-isotope and uranium-series ages of the last carbonates before emergence and the first carbonates deposited after submergence. The Australia plate has converged approximately $52 \mathrm{~km}$ with the New Hebrides Island Arc at a mean rate of $13.2 \pm 1 \mathrm{~cm} / \mathrm{yr}$ since $0.393 \pm .011$ Ma when Bougainville Guyot re-submerged and carbonate sedimentation resumed. This age is based on a precise mass-spectrometric ${ }^{230} \mathrm{Th}$ age measurement and is reliable because the uranium isotopic composition of the sample indicates no diagenetic alteration. The change in convergence rates from 17.2 to $13.2 \mathrm{~cm} / \mathrm{yr}$ indicates a significant change in the opening rate of the North Fiji Basin. However, this conclusion depends on the age of initial opening of the North Fiji Basin. If the North Fiji Basin began to open at $10 \mathrm{Ma}$, then the average opening rate at Espiritu Santo Island has been $6 \mathrm{~cm} / \mathrm{yr}$. If opening began at $12 \mathrm{Ma}$, then the average rate had to be 5 $\mathrm{cm} / \mathrm{yr}$. Because the relative motion between the Australia and Pacific plates is $8.8 \mathrm{~cm} / \mathrm{yr}$, the net convergence rate at the central New Hebrides Island Arc must have averaged 13.8 to $14.8 \mathrm{~cm} / \mathrm{yr}$. Younger dates of initial opening would require higher average convergence rates. If the convergence rate of $13.2 \mathrm{~cm} / \mathrm{yr}$ at Espiritu Santo Island had prevailed for the entire opening of the North Fiji Basin, then the basin would have taken 13-14 m.y. to open at a mean rate of $4.4 \mathrm{~cm} / \mathrm{yr}$. This is contrary to hypotheses for the time of origin of the North Fiji Basin.
\end{abstract}

\section{INTRODUCTION}

In this paper we estimate the average convergence rates between the Australia-India (A) plate and the New Hebrides Island Arc (NHIA) based on the carbonate chronostratigraphy of Bougainville Guyot (BG), drilled at Site 831 of Ocean Drilling Program (ODP) Leg 134 in Vanuatu (Figs. 1 and 2). The net convergence rate at the central NHIA is the vectorial sum of the Australia/Pacific (A/P) plates' relative motion of $8.8 \mathrm{~cm} / \mathrm{yr}$ (DeMets et al., 1990) and the opening rate of the North Fiji Basin (NFB). However, the convergence rates at the NHIA have remained unknown because the contribution from opening of the back-arc NFB has not been known. Some models propose that the NFB contribution is negligible at the central NHIA (Louat and Pelletier, 1989), whereas other models imply a large contribution (e.g., Malahoff et al., 1982; Auzende et al., 1988).

Convergence rates have implications for the tectonics and seismicity of the NHIA. For example, the migration rate of the intersection between the d'Entrecasteaux Zone (DEZ) and NHIA depends on the convergence rate (e.g., Collot and Fisher, 1991; Collot et al., 1992). Therefore, the timing of the tectonic effects of subduction of the DEZ depends on convergence rates. Some geodynamic models relating the magnitude of interplate thrusting earthquakes also depend on accurate estimates of convergence rates (e.g., Ruff and Kanamori, 1980). Finally, many estimates of seismic recurrence intervals are based on plate convergence rates (e.g., Sykes and Quittmeyer, 1981; Taylor et al., 1990).

' Greene, H.G., Collot, J.-Y., Stokking, L.B., et al., 1994. Proc. ODP, Sci. Results, 134: College Station, TX (Ocean Drilling Program).

2 Institute for Geophysics, The University of Texas at Austin, 8701 Mopac Boulevard, Austin, TX 78759-8345, U.S.A.

${ }^{3}$ Department of Geology, University of South Florida, Tampa, FL 33620-5200, U.S.A

${ }^{4}$ Minnesota Isotope Laboratory, Department of Geology and Geophysics, University of Minnesota, 310 Pillsbury Drive, SE, Minneapolis, MN 55455, U.S.A.
Plate convergence rates based on BG apply to time scales ( $10^{5}$ to $10^{6} \mathrm{yr}$ ) not addressed by other methods. It is uncertain whether longer-term plate motion rates $\left(10^{6}\right.$ to $\left.10^{8} \mathrm{yr}\right)$ derived from magnetic anomalies accurately represent rates on shorter time scales. On a still shorter time scale $\left(10^{-1}\right.$ to $\left.10^{1} \mathrm{yr}\right)$, convergence rates are measured using satellite geodetic methods, such as the global positioning system (GPS) or satellite laser ranging (SLR). GPS measurements across the New Hebrides Trench were made in 1989, 1990, and 1992, but the results are not yet published (Bevis et al., 1991). Comparison of GPS results with the convergence rates estimated from BG will be valuable because GPS measurements provide a third completely independent method and time scale.

The stratigraphy of BG records the history of its emergence and subsequent submergence to its present position as it crossed the outer rise of the NHIA (Figs. 2 and 3). Dubois et al. (1988) measured the heights of reefs on islands west of the NHIA to determine the shape of the lithospheric flexure. The flexural curve defines the distances from its present location at which the BG would have emerged and re-submerged as it crossed the outer rise. Carbonate deposition stopped and started, and a subaerial unconformity formed as a result of the emergence and submergence. We have located the subaerial unconformity related to emergence of BG on the outer rise (Fig. 4) and obtained isotopic ages for samples above and below the unconformity. These results provide for calculations of the rates of convergence required for $\mathrm{BG}$ to be at the points of initial emergence and initial re-submergence at the times indicated by the isotopic ages.

\section{METHODS AND PRINCIPLES}

\section{Isotopic Dating}

Quinn et al. (this volume) describe procedures used for strontium isotope dating of the neritic carbonates. Here we discuss the procedures for uranium-series dating of fossil corals from BG (Table 1). Most 


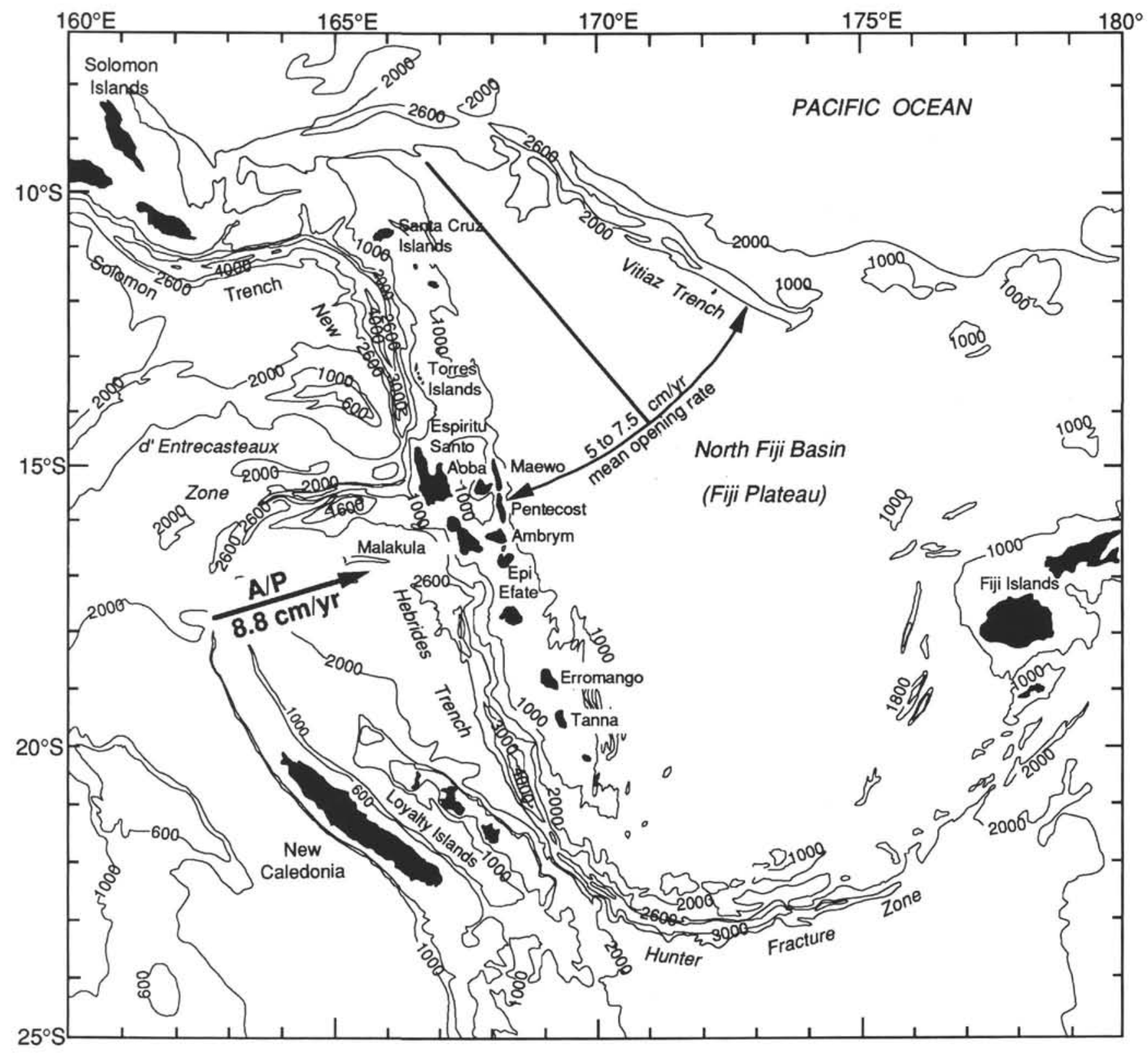

Figure 1. Map of the New Hebrides Island Arc, North Fiji Basin (Fiji Plateau) and Vitiaz Trench. The North Fiji Basin opened by clockwise rotation from the Vitiaz Trench since about 8-12 Ma. Geometry suggests that the central New Hebrides Island Arc rotated about $600 \mathrm{~km}$ from the Vitiaz Trench in 8-12 m.y. at an average rate of 5-7.5 cm/yr, as symbolized on the figure. Added to the $8.8 \mathrm{~cm} / \mathrm{yr}$ Australia/Pacific relative plate-motion vector at Bougainville Guyot, the net average convergence rate at the central New Hebrides Trench must have been on the order of 14-17 cm/yr. Bathymetry after Chase (1971).

fossil corals from the upper $338 \mathrm{mbsf}$ at Site 831 appeared to be well preserved on the basis of absence of calcite cements or inversion of the original skeletal aragonite mineralogy to calcite. However, low recovery rates allowed us to choose from only 15 samples.

We analyzed concentrations of ${ }^{238} \mathrm{U},{ }^{234} \mathrm{U},{ }^{230} \mathrm{Th}$, and ${ }^{232} \mathrm{Th}$ by isotope-dilution thermal-ionization mass spectroscopy in four of the best-preserved fossil coral samples and one replicate at the Minnesota Isotope Laboratory. Techniques are modifications of those described by Edwards et al. (1987). The main differences involve use of a double filament technique for uranium (instead of loading the uranium on a single filament with graphite), and use of a Finnigan 262-RPQ mass spectrometer. This instrument has negligible reflected beams, an abundance sensitivity of $2 \times 10^{-6}$ at mass 237 (after the first stage), a dark noise of 0.05 counts per second, and ion counting capabilities.
Taken together, the technical modifications allowed us to measure uranium isotopic composition 3 times more precisely than Edwards et al. (1987). This capability is important for detecting subtle discordance between ${ }^{234} \mathrm{U} /{ }^{238} \mathrm{U}$ ages and ${ }^{230} \mathrm{Th}$ ages, and is critical for evaluating the accuracy of the ages in this study. A detailed description of our methods will appear in a future publication.

\section{Depositional Model for Bougainville Guyot}

Before drilling began at BG, we could predict its approximate chronostratigraphy based on principles of geodynamics, reef growth (e.g., Neumann and Macintyre, 1985), the geologic setting, and existing knowledge of A/P plate convergence rates (DeMets et al., 1990). However, the contribution of this paper is BG chronostratigraphy, 


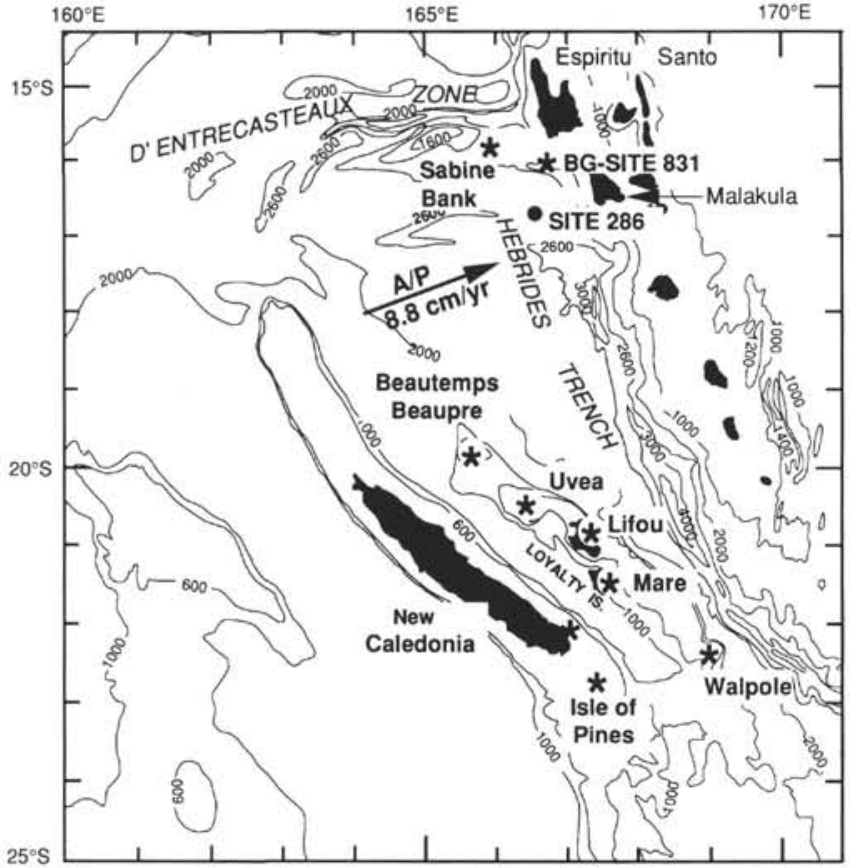

Figure 2. Map of the New Hebrides Island Arc and New Caledonia showing the nine reefs (asterisks) used by Dubois et al. (1988) to define the outer rise lithospheric flexure of the Australia plate prior to subduction at the New Hebrides Island Arc. DSDP Site 286 indicated by filled circle. Bathymetry after Chase (1971).

which places added constraints on the net convergence rates of the $\mathrm{A}$ plate and the NHIA. First we explain the principles by which we can understand the history of BG.

Several geodynamic effects have controlled relative sea-level changes and, thus, carbonate depositional history on BG. Some of these effects are well known and more-or-less predictable. These include thermal subsidence of the lithosphere beneath and adjacent to BG, global sea-level changes related to spreading ridge volume, glacio-eustatic sea-level fluctuations, isostasy, and vertical movements of the A plate as it crosses the outer rise lithospheric flexure of the NHIA(Fig. 5). The timing or magnitude of other effects are poorly known and difficult to predict. These include vertical tectonics of the DEZ related to thermal events in the surrounding lithosphere that may have caused uplift and reset the clock for thermal subsidence.

Bougainville Guyot's vertical motion probably was dominated by thermal subsidence of the DEZ before arriving at the outer rise west of the NHIA. Subsidence rates on the order of several tens of meters per million years are typical of 20 to $50 \mathrm{Ma}$ oceanic lithosphere (Parsons and Sclater, 1977). A paleosol horizon at the boundary between the neritic carbonate cap and andesitic pillow lavas at 727.5 mbsf in Hole 831B suggests that BG was originally a subaerial volcanic edifice (Collot, Greene, Stokking, et al., 1992) (Fig. 4). A volcanic rock sample from 845 mbsf gave a K/Ar age of $37 \pm 1$ Ma (Rex, this volume).

Carbonate deposition on BG has been controlled primarily by its relationship to sea level. We believe that it began as a volcanic edifice around which a fringing reef grew and evolved into a barrier reef and, finally, an atoll, as BG subsided. At times when sea level rose relative to BG and flooded its surface, shallow surface area and carbonate production increased. When sea level dropped down the steep flanks of BG, its surface was subaerially exposed and carbonate deposition ceased. Generally, subsidence and relative sea-level rise create upward growth space on reefs and promote maximum possible coral limestone accumulation rates. However, if relative sea-level rise is too fast and too prolonged for reef growth to keep pace, drowning will ensue.
Our analysis of convergence rates based on BG depends on knowing the A plate lithospheric flexure outboard of the NHIA (Dubois et al., 1988) (Fig. 3). The flexure defines the trajectory followed by BG and the locations at which it emerged and re-submerged on the outer rise flexure. The points of emergence and re-submergence are recorded by cessation and resumption of reef carbonate deposition on BG (e.g., Wheeler and Aharon, 1991). Recognition and dating of the stratigraphic levels within the BG at which these events occurred permit us to estimate convergence rates (i.e., by dividing the known distances by time).

Dubois et al. $(1974,1977,1988)$ investigated the bending of the Eocene lithosphere (Weissel et al., 1982) as it approaches the NHIA subduction zone (Fig. 3). They determined the shape of the lithospheric flexure by plotting the heights of present-day emerged reefs at increasing distances westward from BG, which lies near the seafloor trace of the A/NHIA plate boundary. Dubois et al. (1988) assumed that (1) these reefs had maintained themselves at sea level by upward growth during subsidence until each one in turn approached the NHIA outer rise and began to emerge; (2) their surfaces were not lowered significantly by erosion during subaerial exposure; and (3) the lithosphere behaves elastically. The maximum heights of reefs on these islands are considered to be a record of the net vertical displacement on the outer rise in response to lithospheric flexure. Most of the reefs, such as Lifou and Mare islands (Fig. 2), are emerged atolls.

In our analysis we make several simplifying assumptions with regard to the flexure. The rheological model accounting for the flexure is not important as we are using only the empirical flexural curve defined by the reefs. We assume that the flexure has the same form today as when BG approached the outer rise $229 \mathrm{~km}$ west of its present position. However, the shape of the flexure could change through time as a function of (1) convergence rate; and (2) changes in forces on the margin of the plate due to the amount of resistance to subduction or other effects, or unrecognized variations in lithospheric rheology such as abrupt change in age across a tectonic boundary. We also assume that maximum heights of interglacial sea levels have been similar throughout the Quaternary. We could analyze the influence of every possible uncertainty, but are limiting our analysis to the most significant examples.

Initial estimates of the ages of BG strata that record outer rise events assume that the convergence rate of the A plate with the NHIA has been at least $8.8 \mathrm{~cm} / \mathrm{yr}$ at Espiritu Santo Island (DeMets et al., 1990). Moving at $8.8 \mathrm{~cm} / \mathrm{yr}$ over $229 \mathrm{~km}, 2.6 \mathrm{~m} . \mathrm{y}$. are required for BG to emerge from present sea level to the crest of the outer rise and re-submerge to its present position. The BG crossing of the outer rise should be recorded by the following sequence of events and associated stratigraphic features:

1. Slow thermal subsidence of the lithosphere underlying BG caused slow accumulation of neritic carbonates on a coral atoll surface that maintained itself near the sea surface. Any drops of sea level caused subaerial exposure and freshwater diagenesis of the atoll carbonates deposited before arrival at the outer rise. Slow accumulation rates and repeated subaerial exposure ensured that aragonite corals and high-magnesium calcites are altered almost entirely to low-magnesium calcite.

2. About $229 \mathrm{~km}$ west of its present location, BG arrived at the outer rise and began to tectonically emerge at a very slow rate. This emergence caused prolonged subaerial exposure and a hiatus in carbonate deposition. Fluctuating sea level and vertical migration of a freshwater lens within the carbonates imposed significant diagenetic alteration on the sediments. The guyot passed the crest of the outer rise and began to descend toward the New Hebrides subduction zone.

3. Because the flexural curve slope increases closer to the plate boundary, the BG subsidence rate accelerated after it passed the crest of the outer rise. Approximately $52 \mathrm{~km}$ west of the present position of BG seawater again flooded its surface. Coral reefs recolonized the atoll surface and coral limestone was deposited to maintain the atoll 


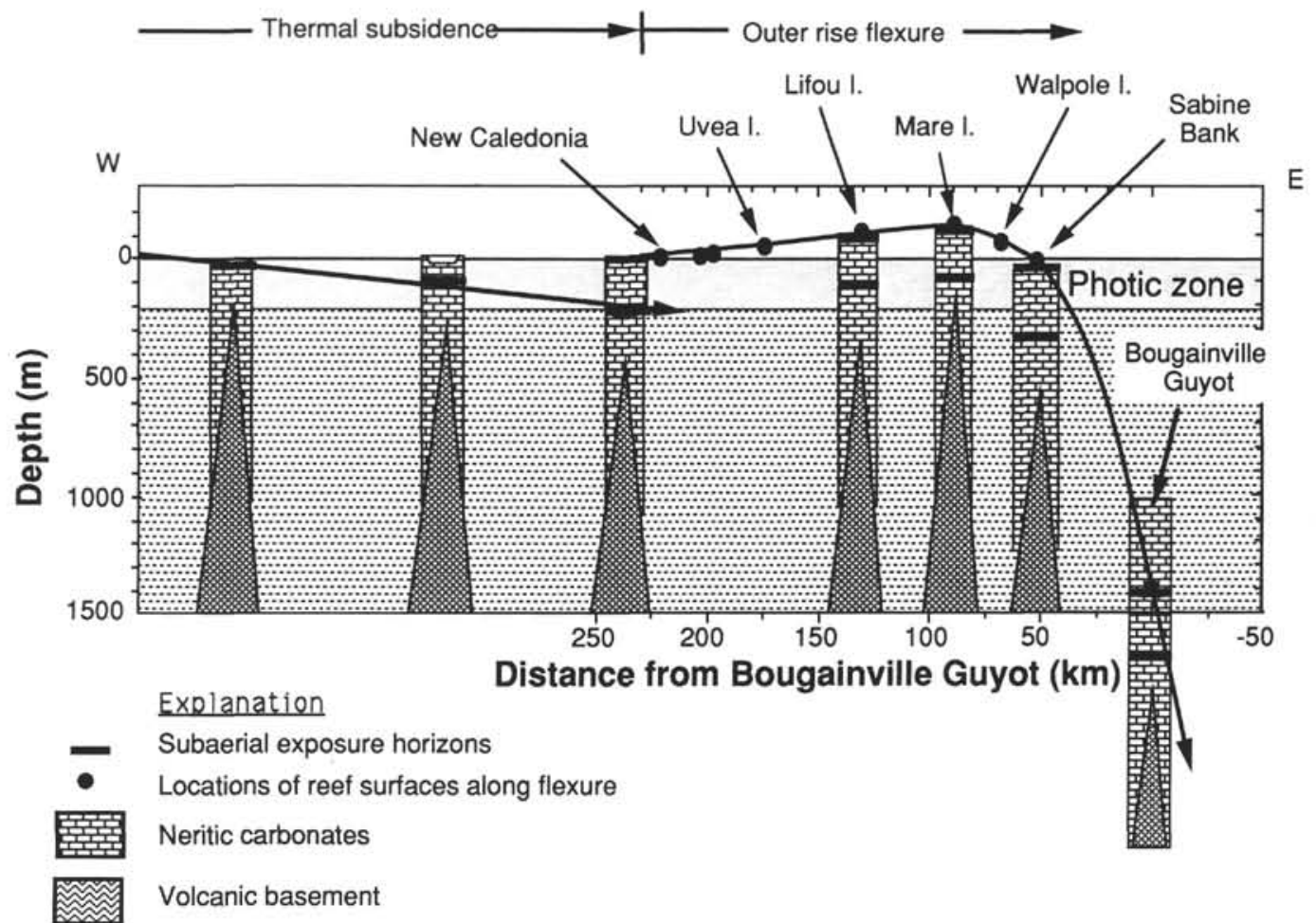

Figure 3. Heavy black lines indicate the trajectory that Bougainville Guyot followed to its present position based on emerged reefs on the outer rise flexure (Dubois et al., 1988). Distances west of the outer rise are not to scale. Before arrival at the outer rise, Bougainville Guyot was an atoll slowly subsiding at a rate dictated by cooling of the Eocene lithosphere on which it rests. This rate is about $10-15 \mathrm{~m} / \mathrm{m} . \mathrm{y}$. for lithosphere of this age (e.g., Parsons and Sclater, 1977). Upward reef growth kept pace with the relative rise of sea level until Bougainville Guyot approached the edge of the outer rise at about $229 \mathrm{~km}$. The guyot began to emerge and coral limestone ceased to be deposited on its surface. This subaerially exposed surface is the marker horizon recording the upward deflection of the Australia plate lithosphere as it crossed the outer rise. When Bougainville Guyot re-submerged at about $52 \mathrm{~km}, 350 \mathrm{~m}$ of coral limestone deposition ensued. Thus, the surface of Bougainville Guyot at Site 831 is at $1066 \mathrm{~m}$ below sea level (mbsl), but the subaerial exposure horizon formed on the outer rise is at about $338 \mathrm{~m}$ below seafloor (mbsf), or $1404 \mathrm{mbsl}$, and reflects total subsidence from sea level.

surface near sea level as it subsided. A marked unconformity would occur between the underlying diagenetically altered carbonates that crossed the outer rise and the newly deposited neritic carbonates. The subsidence rate at this point on the BG trajectory was about $1 \mathrm{~mm} / \mathrm{yr}$, assuming a convergence rate of $8.8 \mathrm{~cm} / \mathrm{yr}$. For the last $52 \mathrm{~km}$ of BG horizontal motion, the mean subsidence rate averaged at least 2.38 $\mathrm{mm} / \mathrm{yr}$, if the convergence rate was $8.8 \mathrm{~cm} / \mathrm{yr}$. Therefore, the surface exposed on the outer rise descended from sea level to $1404 \mathrm{mbsl}$ while moving $52 \mathrm{~km}(2.38 \mathrm{~mm} / \mathrm{yr}=1404 \mathrm{~m} /[52 \mathrm{~km} / 8.8 \mathrm{~cm} / \mathrm{yr}])$.

4. Quaternary sea level fluctuated and the BG surface was intermittently subaerially exposed. This intermittent exposure resulted in freshwater lens migration and a mild diagenetic overprint. These carbonates were altered much less than the underlying carbonates that were exposed during the time period while $\mathrm{BG}$ crossed the outer rise.

5 . The acceleration of BG subsidence (several millimeters per year) ultimately caused upward growth to fail to keep pace during periods of rapidly rising global sea levels, and the atoll probably drowned. Pelagic carbonate deposition succeeded neritic sedimentation.

In summary, this model indicates that 3 main carbonate units should record the transit of BG across the NHIA outer rise.

1. The lowest unit would be early Pleistocene to late Pliocene in age and contain evidence of extensive freshwater diagenesis. A subaerial exposure horizon, if preserved, would mark an unconformity at the top of the lowest unit.
2. The middle unit, located immediately above the unconformity, would be of late Pleistocene age and would consist of well-preserved neritic carbonates having minimal evidence of fresh-water diagenesis because of rapid tectonic subsidence rates, but possibly a considerable amount of marine diagenesis.

3. The uppermost unit would be late Pleistocene to Holocene in age and consist of pelagic carbonates.

\section{STRATIGRAPHY AND ISOTOPIC AGES OF BOUGAINVILLE GUYOT}

The surface of BG is approximately $10 \mathrm{~km}$ by $20 \mathrm{~km}$, lies at a mean depth of approximately $1000 \mathrm{mbsf}$, and slopes approximately $5^{\circ}$ toward the east. It presently impinges on the western edge of the NHIA, but there is no evidence that it is detached from the A plate (Dubois et al., 1988; Collot et al., 1992).

Holes $831 \mathrm{~A}$ and $831 \mathrm{~B}$ are located near the center of BG; drilling started at $1066 \mathrm{mbsl}$ and penetrated to $852 \mathrm{mbsf}$ (Fig. 4), of which the upper $727.5 \mathrm{mbsf}$ are carbonate sediment and the interval from 727.5 to $852 \mathrm{mbsf}$ is andesitic breccia. The interval from 0 to $16.9 \mathrm{mbsf}$ (lithostratigraphic Unit I) is dominated by a foraminiferal ooze with a variety of mollusk and echinoid fragments that indicate pelagic sedimentation. Unit II, from 16.9 to 429.6 mbsf, starts with an abrupt transition to neritic carbonate fossils associated with hermatypic coral reefs. Below this level, lithostratigraphic Unit III is dominated by mollusk- and foraminifer-rich sediment. Fossil corals are rare in Unit III. 


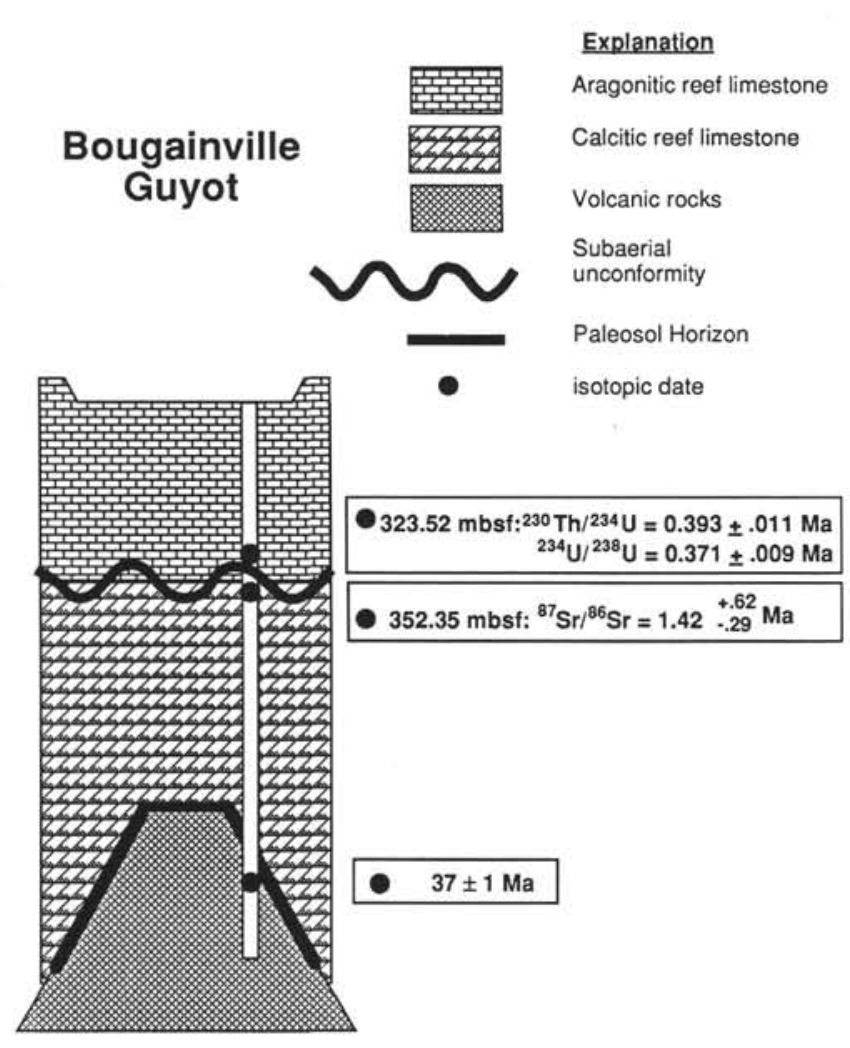

Figure 4. Schematic stratigraphic section of Bougainville Guyot showing a major unconformity at about $338 \mathrm{mbsf}$ at Hole 831B. Isotopic ages just below and just above the unconformity indicate approximately $1 \mathrm{~m} . \mathrm{y}$. of subaerial exposure on the outer rise. This unconformity consists of a change of coral mineralogy from mostly calcite below to mostly aragonite above. Freshwater diagenesis below the unconformity during subaerial exposure altered much of the aragonite and high-magnesium calcite to low-magnesium calcite. Recolonization by coral reefs at the time of re-submergence led to renewed deposition of neritic and, finally, pelagic carbonates. Rapid submergence minimized subaerial exposure and the effects of freshwater diagenesis so that the original aragonite mineralogy of fossil corals is preserved.

Calcite cement is minor in Subunits IIA, IIB, and IIC, but secondary sparry calcite cement becomes abundant in Subunit IID beginning at $352.35 \mathrm{mbsf}$ and dominates in Unit III, which extends from 429.6 to $727.5 \mathrm{mbsf}$. Quinn et al. (this volume) find a dramatic increase in the percentage of calcite at $352.35 \mathrm{mbsf}$. The poor recovery of samples between 323.5 and 362 mbsf causes some ambiguity for the exact point at which the calcite percentage increases. We estimate the appearance of calcite cement to indicate a significant increase in freshwater diagenesis below about 338 mbsf.

Strontium isotope ages provide the overall chronological framework for the carbonate stratigraphy of BG (Quinn et al., this volume). About 15 strontium ages for samples from 100 to 400 mbsf show that the neritic carbonates of the upper $391 \mathrm{mbsf}$ of BG are in the $0.2-1.7$ $\mathrm{Ma}$ age range. A sample from $352.35 \mathrm{~m}$ (minimal depth because the only samples from Core $831 \mathrm{~B}-30 \mathrm{R}$ were from the core catcher) gave an age of $1.42 \mathrm{Ma}$. (The bottom of the core interval from which this core-catcher sample was recovered is $362 \mathrm{~m}$. Its official depth is near the top of the core, but the sample may have come from the bottom.) Below $400 \mathrm{mbsf}$, the ages increase to more than $10 \mathrm{Ma}$ at $410.31 \mathrm{mbsf}$.

In the upper $323.52 \mathrm{~m}$ of the BG (Table 1), uranium-series ages provide much better time resolution than do strontium isotope ages. Uranium-series ages are limited to the upper $323.52 \mathrm{mbsf}$ where high-quality coral samples occurred. All of the uranium-series ages indicate that the age of at least the upper $323.52 \mathrm{~m}$ of BG is $<0.6 \mathrm{Ma}$.
However, the lack of concordance between ${ }^{230} \mathrm{Th}$ and ${ }^{234} \mathrm{U} /{ }^{238} \mathrm{U}$ ages in 3 samples is probably caused by leakage of ${ }^{234} U$ related to alpharecoil processes (Edwards et al., 1991). This would cause the calculated ages to be older than the samples so that most of these should be considered maximum possible ages.

In contrast, the sample from $323.52 \mathrm{mbsf}$ gives nearly concordant ages of $0.371 \pm .009 \mathrm{Ma}$ and $0.393 \pm .011 \mathrm{Ma} \mathrm{by}{ }^{234} \mathrm{U}^{238} \mathrm{U}$ and ${ }^{230} \mathrm{Th}$, respectively. This sample also has higher initial ${ }^{234} U /{ }^{238} U$ values, indicating there was minimal diagenetic alteration (Table 1). This age probably represents the timing of sediment deposition at $323.52 \mathrm{mbsf}$ on BG.

Between 338 and 727.5 mbsf the strontium ages indicate several additional hiatuses in carbonate deposition. The absence of samples giving particular ages does not prove that sediment of those ages does not exist in the BG, but large time gaps over small intervals strongly suggest major hiatuses. These include the following intervals: 10.68 to $1.66 \mathrm{Ma}, 17.29$ to $10.68 \mathrm{Ma}$, and 30.28 to $24.17 \mathrm{Ma}$ (Quinn et al., this volume).

\section{INTERPRETATION OF CONVERGENCE RATES FROM THE CHRONOSTRATIGRAPHY OF BOUGAINVILLE GUYOT}

The stratigraphy of BG is consistent with that predicted by the stratigraphic model based on the outer rise flexure. Above $338 \mathrm{mbsf}$ BG consists of essentially unaltered carbonates that give mid-Quaternary strontium-isotope and uranium-series ages (Fig. 4; Table 1). The dramatic increase in calcite in the interval below 338 mbsf indicates the presence of a subaerial exposure surface that formed while BG was emerged near the crest of the outer rise. The upper $338 \mathrm{mbsf}$ of carbonate sediment was deposited since BG began to re-submerge about $52 \mathrm{~km}$ west of its present position. A sample from $323.52 \mathrm{mbsf}$ has the best ${ }^{230} \mathrm{Th}$ age of $0.393 \pm .011 \mathrm{Ma}$. This is approximately the time when carbonate deposition resumed just above the inferred unconformity. Immediately below the inferred unconformity at 352.35 mbsf is a sample with a strontium isotope age of $1.42 \pm_{0.29}^{0.62} \mathrm{Ma}$. This approximates the time of the last carbonate deposition on BG before it encountered the outer rise and began to emerge.

Given the times when BG was at distances of approximately 229 $\mathrm{km}(1.42 \mathrm{Ma}), 52 \mathrm{~km}(0.393 \mathrm{Ma})$, and at its present position $(0 \mathrm{~km}$ and $0 \mathrm{Ma}$ ) we can calculate average convergence rates (Fig. 6). It required $1.027 \mathrm{~m} . y$. to move from 229 to $52 \mathrm{~km}$. Therefore, the average rate of convergence from 1.42 to $0.393 \mathrm{Ma}$ was $17.2 \mathrm{~cm} / \mathrm{yr}$. From $0.393 \mathrm{Ma}$ to present BG must have moved $52 \mathrm{~km}$ to its present location, for an average convergence rate of $13.2 \mathrm{~cm} / \mathrm{yr}$. For the entire interval from 1.42 Ma to present the total convergence was $229 \mathrm{~km}$ at an average rate of $16.1 \mathrm{~cm} / \mathrm{yr}$.

Error bars for convergence rates based on strontium ages (Fig. 7) are large, in part because of the relatively slow rate of change for strontium isotope ratios in the oceans (DePaolo and Ingram, 1985). In terms of convergence rates, these errors alone $(2 \sigma)$ are on the order of $\pm 7 \mathrm{~cm} / \mathrm{yr}$. However, the dates determined by concordant uraniumseries dates have extremely small analytical errors (Edwards et al., $1987 ; 1988$ ). Thus, analytical errors in ${ }^{230} \mathrm{Th}$ ages and the halflife of ${ }^{230} \mathrm{Th}$ cause errors of only about $\pm 1 \mathrm{~cm} / \mathrm{yr}$ in the calculated convergence rates.

Additional sources of possible error include (1) uncertainty in the location of emergence ( $229 \mathrm{~km}$ ?) and submergence $(52 \mathrm{~km}$ ?) due to errors in the flexural curve; (2) uncertainty in the location of emergence and submergence due to paleosea levels quite different from present when the BG began and ended its interval of subaerial exposure on the outer rise (Fig. 8); and (3) subaerial erosion of the emergent islands on the outer rise causing removal of the last corals deposited before emergence. For example, the flexural curve has a small positive slope at the western edge of the outer rise. The point of initial emergence would change by about $1 \mathrm{~km}$ in horizontal position per meter change in vertical position. However, for the point 
Table 1. ${ }^{230}$ Th and ${ }^{234} \mathrm{U} /{ }^{238} \mathrm{U}$ ages determined by thermal ionization mass spectrometric analyses.

\begin{tabular}{|c|c|c|c|c|c|}
\hline $\begin{array}{l}\text { Core, section, } \\
\text { interval }(\mathrm{cm})\end{array}$ & $\begin{array}{l}\text { Depth } \\
\text { (mbsf) }\end{array}$ & $\begin{array}{c}\delta^{234} U^{a} \\
\text { Measured }\end{array}$ & $\begin{array}{c}{ }^{230} \mathrm{Th}^{\mathrm{b}} \\
\text { Age }(\mathrm{Ma})\end{array}$ & $\begin{array}{c}\delta^{234} U^{c} \\
\text { Initial }\end{array}$ & $\begin{array}{c}{ }^{234} \mathrm{U}^{238} \mathrm{U}^{\mathrm{d}} \\
\text { Age (Ma) }\end{array}$ \\
\hline 831B-3R-CC, $6-8$ & 112.0 & $29.1 \pm 2.5$ & - & - & $0.576 \pm .030$ \\
\hline $831 \mathrm{~B}-7 \mathrm{R}-1,14-16$ & 140.64 & $23.0 \pm 2.0$ & $0.392 \pm \pm_{0.013}^{0.014}$ & $70 \pm 7$ & $0.659 \pm .030$ \\
\hline $831 \mathrm{~B}-18 \mathrm{R}-1,110-125$ & 238.3 & $26.3 \pm 1.2$ & $0.450 \pm \pm_{0.018}^{0.020}$ & $94 \pm 7$ & $0.612 \pm .015$ \\
\hline $831 \mathrm{~B}-18 \mathrm{R}-2,46-48$ & 238.91 & $27.2 \pm 1.5$ & $0.445 \pm_{0.015}^{0.017}$ & $96 \pm 7$ & $0.600 \pm .020$ \\
\hline 831B-27R-CC, $12-14$ & 323.52 & $52.1 \pm 1.3$ & $0.393 \pm 0.012$ & $159 \pm 7$ & $0.371 \pm .009$ \\
\hline
\end{tabular}

Note: All errors are $2 \sigma$.

${ }^{a} \delta^{234} \mathrm{U}=\left\{\left\{\left({ }^{234} \mathrm{U} /{ }^{238} \mathrm{U}\right) /\left(5.472 \times 10^{-5}\right)\right\}-1\right\}\left\{10^{3}\right\}$, where ${ }^{234} \mathrm{U} /{ }^{238} \mathrm{U}$ is the measured atomic ratio and 5.472 $\times 10^{-5}$ is the atomic ${ }^{234} \mathrm{U} / 238 \mathrm{U}$ ratio in a system at secular equilibrium, calculated from the ratio of the decay constants for ${ }^{234} \mathrm{U}\left(2.835 \times 10^{-6} \mathrm{y}^{-1}\right.$; Lounsbury and Durham, 1971; de Bievre et al., 1971) and ${ }^{238} \mathrm{U}\left(1.551 \times 10^{-10} \mathrm{y}^{-1}\right.$; Jaffey et al., 1971).

b $230 \mathrm{Th}$ ages are calculated from the following equation: $\left[{ }^{230} \mathrm{Th} / 238 \mathrm{U}\right]_{\text {act }}-1=-\mathrm{e}^{-|\lambda(230) \mathrm{T}\rangle}+$ $\left.\left.\left.\left.\left\{\delta^{234} \mathrm{U} / 1000\right\}|\lambda(230) /| \lambda(230)-\lambda(234)\right\}\right] \mid 1-\mathrm{e}^{-\{\lambda(230)}-\lambda(234)\right\} \mathrm{T}\right\}$, where $\left[{ }^{230} \mathrm{Th} /{ }^{238} \mathrm{U}\right]_{\text {act }}$ is the ${ }^{230} \mathrm{Th} /{ }^{238} \mathrm{U}$ activity ratio and is equal to the measured ${ }^{230} \mathrm{Th} / 238 \mathrm{U}$ atomic ratio times $1.6871 \times 10^{-5}$, which is the ratio of the decay constants for ${ }^{238} \mathrm{U}$ and ${ }^{230} \mathrm{Th}\left(9.195 \times 10^{-6} \mathrm{y}^{-1}\right.$, Meadows et al., 1980). $\lambda(230)$ and $\lambda(234)$ are the ${ }^{230} \mathrm{Th}$ and ${ }^{234} \mathrm{U}$ decay constants; T is the ${ }^{230} \mathrm{Th}$ age. The "- " in the first row indicates that the isotopic composition was such that the ${ }^{230} \mathrm{Th}$ age equation could not be solved.

c Initial $\delta^{234} \mathrm{U}$ is calculated from the measured $\delta^{234} \mathrm{U}$ and ${ }^{230} \mathrm{Th}$ age using the equation: Initial $\delta^{234} \mathrm{U}=$ \{Measured $\delta^{234} \mathrm{U}$ ] $\left[\mathrm{e}^{\lambda(234) \mathrm{T}}\right.$ ]. The "- " in the first row indicates that initial $\delta^{234} \mathrm{U}$ could not be calculated because the ${ }^{230} \mathrm{Th}$ age equation in the column to the left could not be solved.

${ }^{d}$ The ${ }^{234} U / 238 U$ age is calculated from the equation: $T^{\prime}=\left\{\ln \left\{149.7 /\right.\right.$ Measured $\left.\left.\delta^{234} U\right\}\right\} / \lambda(234)$, where $149.7 \pm 1.5$ is the $\delta^{234} U$ value of modern corals (Edwards et al., 1993).

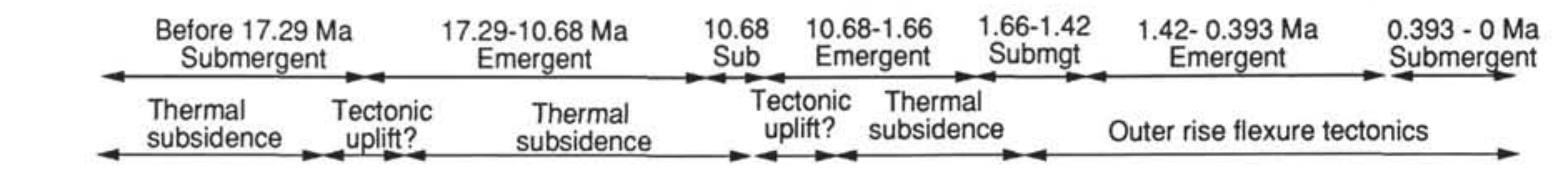

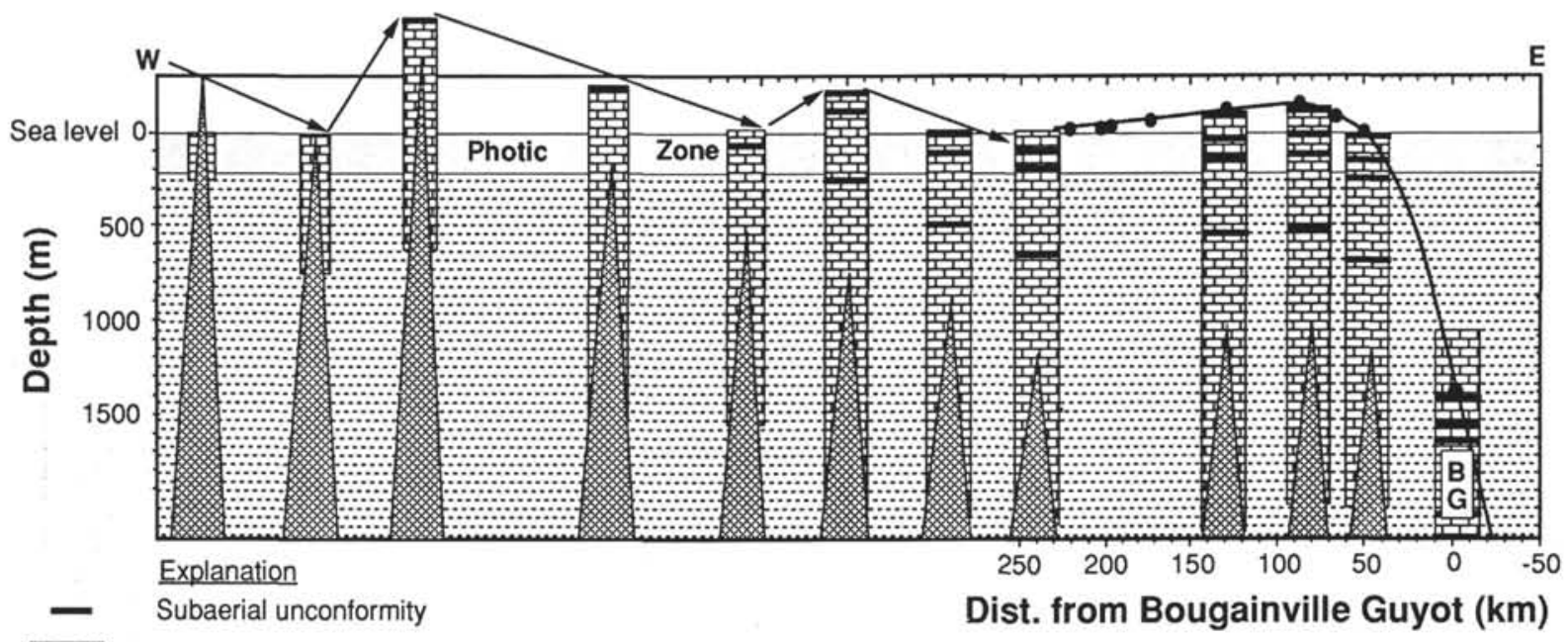

Neritic carbonates

Volcanic rocks

Figure 5. Schematic diagram of the carbonate deposition history on the Bougainville Guyot. Apparent major hiatuses in the carbonate record occur between approximately 17.29 and $10.68 \mathrm{Ma}$, between 10.68 and $1.66 \mathrm{Ma}$, and during the time the Bougainville Guyot was emerged on the outer rise from 1.42 to $0.393 \mathrm{Ma}$. Tectonic uplift or major sea-level lowering may have caused the pre-Pleistocene hiatuses.

at which the BG began to re-submerge the flexural curve has a strong negative slope and the horizontal change will be about $1 \mathrm{~km}$ per 10 $\mathrm{m}$ of change in vertical position. The position of Sabine Bank at a distance of $52 \mathrm{~km}$ gives the minimum distance for re-submergence of BG. Thus, the distance over which BG moved since it re-submerged could be increased slightly, but is very unlikely to be less than $52 \mathrm{~km}$.
This suggests that rates greater than $13.2 \mathrm{~cm} / \mathrm{yr}$ are more likely than slower rates. If, for example, there is a 50-m-thick cap of post-submergence carbonates on Sabine Bank, then the submergence point of BG would be moved back to about $57 \mathrm{~km}$ and the mean convergence rate since $0.393 \mathrm{Ma}$ would be $14.5 \mathrm{~cm} / \mathrm{yr}$. The location of Walpole Island with an altitude of $71 \mathrm{~m}$ at a distance of $68 \mathrm{~km}$ limits the greatest 


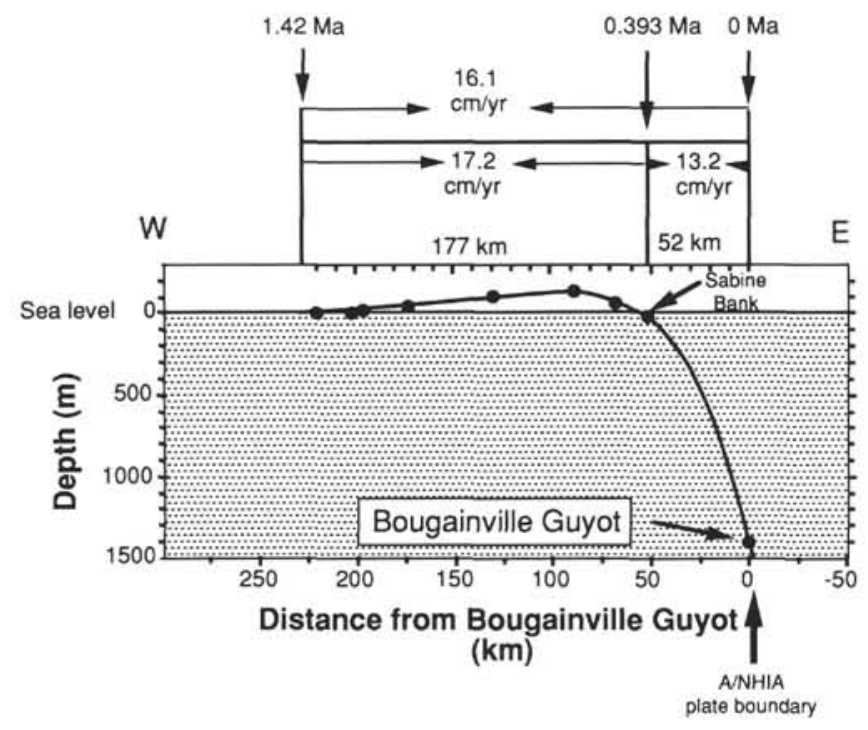

Figure 6. Times of emergence at $229 \mathrm{~km}$, re-submergence at $52 \mathrm{~km}$, and present location and ages from stratigraphic horizons (Fig. 4) for Bougainville Guyot plotted on the outer rise profile of Dubois et al. (1988). Required average convergence rates are $16.1 \mathrm{~cm} / \mathrm{yr}$ for $229 \mathrm{~km}$ to $0 \mathrm{~km} ; 17.2 \mathrm{~cm} / \mathrm{yr}$ for 229 to $52 \mathrm{~km}$, and $13.2 \mathrm{~cm} / \mathrm{yr}$ for 52 to $0 \mathrm{~km}$. These data suggest that the convergence rate changed at least one time during the past $1.42 \mathrm{~m} . \mathrm{y}$.

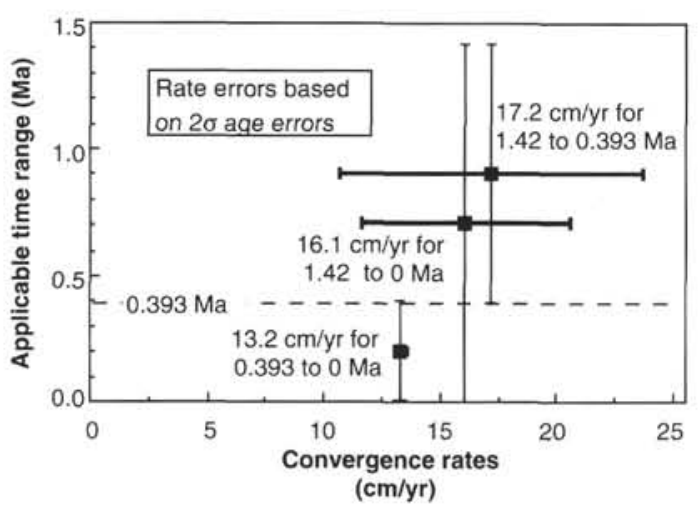

Figure 7. Horizontal error bars $(2 \sigma)$ for the average convergence rates are calculated on the basis of the analytical errors for isotopic ages and distances on the outer rise trajectory. The vertical bars represent the time interval over which each average rate prevailed. These errors do not consider imprecision in the flexural curve and sample contamination. The smallest change in convergence rate would be required if it occurred at $0.393 \mathrm{Ma}$. Therefore, the error bars have maximum overlap at $0.393 \mathrm{Ma}$. Error bars have less overlap for changes in convergence rate that occurred at any time other than $0.393 \mathrm{Ma}$ because the amount of change would have to be larger.

distance for re-submergence of BG (Figs. 3 and 8). Over 1 m.y. erosion would not lower the BG surface by more than a few meters (e.g., Quinn and Matthews, 1990; Quinn, 1991) and would influence the point of re-submergence by no more than 1 or $2 \mathrm{~km}$.

If $\mathrm{BG}$ became detached from the A plate when it impinged on the NHIA, then it might have ceased to move eastward. However, previous studies have not discovered evidence for detachment (Collot, Greene, Stokking, et al., 1992; Fisher et al., 1991; Collot and Fisher, 1991; Collot et al., 1992; Montaggioni et al., 1991).

Nature has recorded average convergence rates in BG for 2 time intervals not of our choosing. Our calculated convergence rates may consist of combinations of different rates. Actual rates may not corre-

\section{A $\quad 1.42 \mathrm{Ma}$}

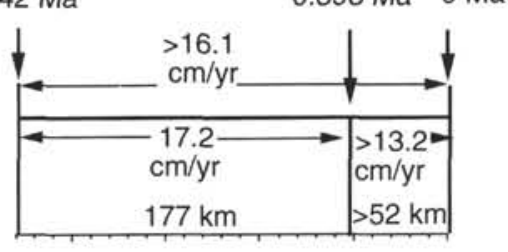

B

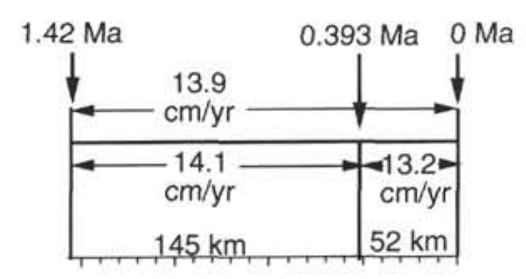

C
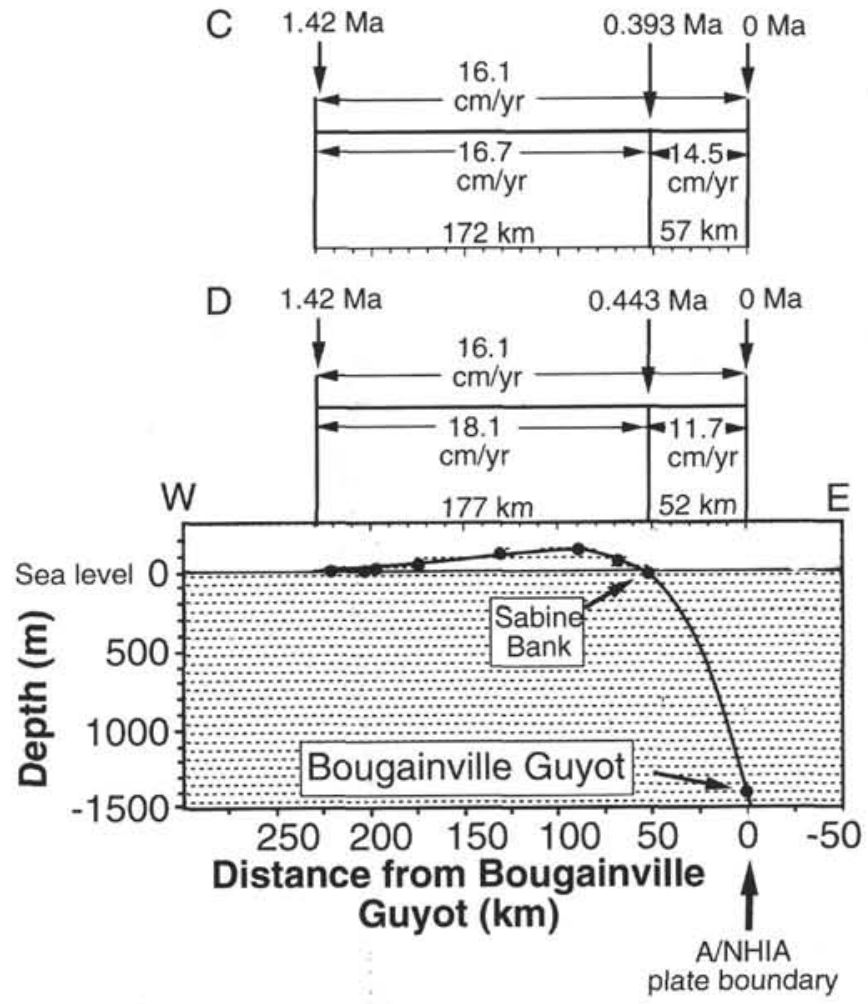

Figure 8. Examples of the effects of several possible uncertainties on the estimates of convergence rates. A. The position of Bougainville Guyot underestimates the amount of convergence because of collision with the New Hebrides Island Arc. Bougainville Guyot has been sheared off the downgoing plate, the d'Entrecasteaux Zone is pushing the plate boundary eastward, or the edge of the Australia plate crust is detaching from the asthenosphere. Any of the above, as well as other phenomena would affect the estimate of the convergence rate during the interval from 0.393 to $0 \mathrm{Ma}$. B. Sea level when Bougainville Guyot began to emerge on the outer rise was $20 \mathrm{~m}$ higher than present. Bougainville Guyot would have begun to emerge from the sea at 197 $\mathrm{km}$ rather than $229 \mathrm{~km}$ west of its present position. The convergence rate from 1.42 to $0.393 \mathrm{Ma}$ would have been 14.1 instead of $17.2 \mathrm{~cm} / \mathrm{yr}$. C. Bougainville Guyot descended from the outer rise and reached present sea level at 57 rather than $52 \mathrm{~km}$ west of its present position. The convergence rates would then be 16.7 and $14.5 \mathrm{~cm} / \mathrm{yr}$ rather than 17.2 and $13.2 \mathrm{~cm} / \mathrm{yr}$. D. Bougainville Guyot descended from the outer rise and reached present sea level at $52 \mathrm{~km}$ west of its present position, but it arrived during a low stand of sea level. Reef growth on the surface of the Bougainville Guyot was delayed so that the corals that we sampled underestimate the timing of arrival at $52 \mathrm{~km}$ by 50,000 years. The rates would thus be 18.1 and $11.7 \mathrm{~cm} / \mathrm{yr}$ rather than 17.2 and $13.2 \mathrm{~cm} / \mathrm{yr}$. 
spond to the average rates. We now consider several possible scenarios that might have produced the observed average rates. To limit the range of possibilities we introduce some simplifying assumptions:

1. Since $1.42 \mathrm{Ma}$ when BG reached the outer rise there has been a single change from a faster convergence rate, $R_{w}$, to a slower convergence rate, $R_{e}$, and this change occurred $T$ years before present. There could have been more than one change of rate, but we choose to assume only one. $\mathrm{cm} / \mathrm{yr}$.

2. The average convergence rate from $1.42 \mathrm{Ma}$ to $0.393 \mathrm{Ma}$ is 17.2

3. The average convergence rate from 0.393 to $0 \mathrm{Ma}$ is $13.2 \mathrm{~cm} / \mathrm{yr}$.

Given these assumptions we can consider three possible cases depending on whether the rate change from $R_{w}$ to $R_{e}$ occurred at, before, or after $0.393 \mathrm{Ma}$ (Figs. 9 and 10). For all three cases the total convergence must satisfy the equation:

$$
229 \mathrm{~km}=R_{w}(1.42-T)+R_{e} T .
$$

Case 1: The change in rate occurred at $T=0.393 \mathrm{Ma}$ and thus, by assumptions 2 and $3, R_{w}$ was $17.2 \mathrm{~cm} / \mathrm{yr}$ and $R_{e}$ was $13.2 \mathrm{~cm} / \mathrm{yr}$. This is possible, but unlikely.

Case 2: The rate decreased sometime before $0.393 \mathrm{Ma}$, thus 0.393 m.y. $<T<1.42$ m.y. The possible combinations of rates (Figs. 9 and 10) that would fulfill this and the assumptions satisfy the equation:

$$
R_{w}=\frac{229 \mathrm{~km}-(13.2 \mathrm{~cm} / \mathrm{yr} T)}{(1.42-T)} .
$$

Case 3: The rate changed after $0.393 \mathrm{Ma}$, so $T<0.393$ m.y. Therefore, the earlier, faster rate of $17.2 \mathrm{~cm} / \mathrm{yr}$ prevailed until the slower rate, $R_{e}$, ensued sometime after $0.393 \mathrm{Ma}$. In this case, the assumptions require:

$$
R_{e}=\frac{229-[17.2 \mathrm{~cm} / \mathrm{yr}(1.42-T)]}{T} .
$$

Overlap of error bars (Fig. 7) for the two mean convergence rates is greatest if a change in rate occurred at $T=0.393$ Ma because in this case the two average rates are most similar. At other times the difference in rates is greater and the overlap is less. For example, if the change in rate occurred at $1.0 \mathrm{Ma}$, then the two rates would have been 23 and $13.2 \mathrm{~cm} / \mathrm{yr}$, and there would be no overlap. Likewise if the change was at $0.2 \mathrm{Ma}$, the rates would have been 17.2 and $9 \mathrm{~cm} / \mathrm{yr}$, and there would be no overlap.

\section{DISCUSSION}

Dubois et al. $(1974,1977)$ introduced the idea of using vertically displaced reefs on outer rises to estimate convergence rates. They considered coral reef uplift rates of the Loyalty Islands and Niue Island to be a function of convergence rate for reefs ascending the outer rise flexures for the NHIA and Tonga Island Arc, respectively. They found convergence rates of about $12 \mathrm{~cm} / \mathrm{yr}$ for the New Hebrides arc and $9 \mathrm{~cm} / \mathrm{yr}$ for the Tonga Island Arc.

However, convergence rates based on uplift rates are unlikely to be as accurate as our results because they are extremely sensitive to errors in (1) the slope of the flexural curves at the location of each emerged reef; (2) measurements of the amounts of emergence and the age of each emerged reef; and (3) the paleosea-level correction factor for each emerged reef. For example, as recognized by Dubois et al. (1977), an error of $1 \mathrm{~m}$ in the amount of uplift of an $0.08 \mathrm{Ma}$ reef causes an error of about $1 \mathrm{~cm} / \mathrm{yr}$ in the convergence rate.

Convergence rates based on the chronostratigraphy of BG do not depend on vertical displacement rates. Instead, we use the horizontal

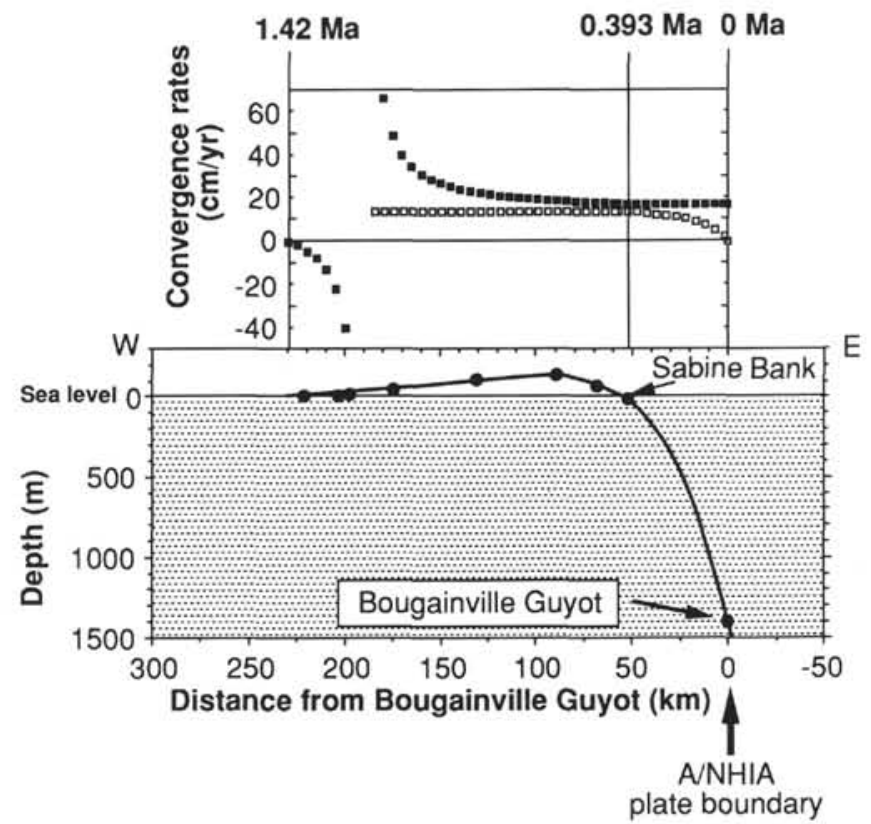

Figure 9. The lower part of the figure shows the trajectory assumed for Bougainville Guyot across the outer rise. The points in the upper graph show combinations of two convergence rates $\mathrm{v}$. location along the profile that could produce the mean convergence rates shown in Figure 6. The filled squares represent the higher of each pair of rates and the open squares represent the lower rate of each pair. A single change of rate was unlikely to have occurred more than $170 \mathrm{~km}$ from Bougainville Guyot. If a change to the $13.2 \mathrm{~cm} / \mathrm{yr}$ rate started at a greater distance, then the earlier, higher matching rate would have had to be infinite for Bougainville Guyot to move from 229 to $170 \mathrm{~km}$ and produce an average convergence rate of $17.2 \mathrm{~cm} / \mathrm{yr}$ between 1.42 and $0.39 \mathrm{Ma}$.

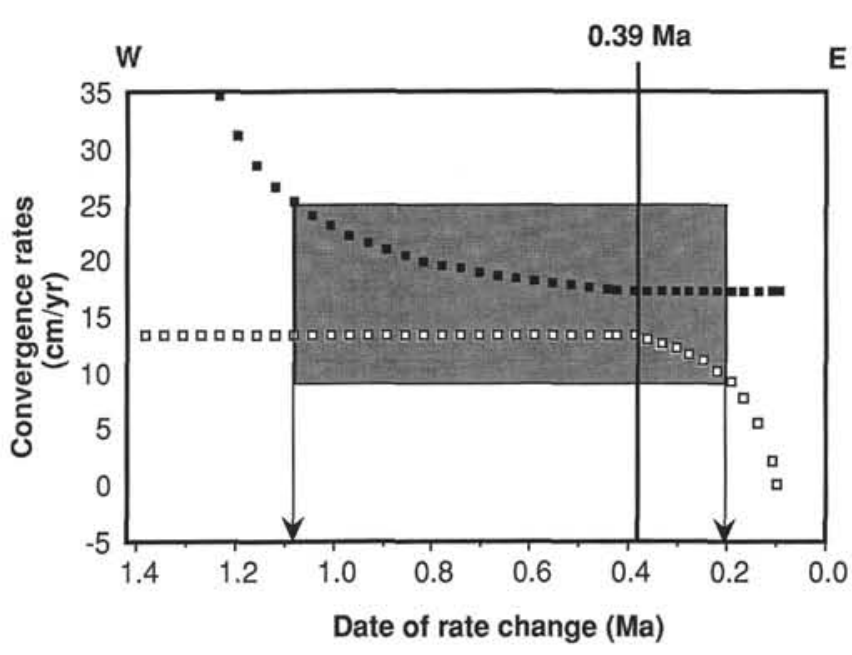

Figure 10. Pairs of convergence rates versus time when a single change of rate might have occurred. The higher rate of each pair is a black square and the lower rate is an open square. The shaded box encloses the ranges of rates that we consider reasonable. If a change in convergence rate occurred after $0.1 \mathrm{Ma}$, then the slower convergence rate would have to be $0 \mathrm{~cm} / \mathrm{yr}$ to maintain the average convergence rate of $13.2 \mathrm{~cm} / \mathrm{yr}$ since $0.393 \mathrm{Ma}$. The rate is unlikely to have fallen below the Australia-Pacific relative rate of $8.8 \mathrm{~cm} / \mathrm{yr}$ at this location (DeMets et al., 1990) so that a change of rate is unlikely to have occurred after $0.2 \mathrm{Ma}$. We suggest an upper limit of 25 or perhaps $30 \mathrm{~cm} / \mathrm{y}$ which limits the earliest date for a rate change to about $1.2 \mathrm{Ma}$. Therefore a change of rate is more likely to have occurred between 1.2 and $0.2 \mathrm{Ma}$. 
distances over which BG moved during two intervals of time defined by isotopic ages.

Approximately $600 \mathrm{~km}$ of NFB opening is required at Espiritu Santo since 8-12 Ma (Auzende et al., 1988; Eissen et al., 1991) to separate the central NHIA from the Vitiaz Trench. This requires a mean NFB opening rate of 5 to $7.5 \mathrm{~cm} / \mathrm{yr}$ at the central NHIA. Adding this rate to the $8.8 \mathrm{~cm} / \mathrm{yr}$ of $\mathrm{A} / \mathrm{P}$ relative plate motion at the present location of BG (DeMets et al., 1990) obtains a net mean convergence rate of 13.8 to $16.3 \mathrm{~cm} / \mathrm{yr}$. This is consistent with the rate of $17.2 \mathrm{~cm} / \mathrm{yr}$ that we obtained from 1.42 to $0.393 \mathrm{Ma}$. The convergence rate since $0.393 \mathrm{Ma}$ is too slow to allow a sufficient opening rate for the NFB. At the mean rate for the past $0.393 \mathrm{~m} . \mathrm{y}$. of only $13.2 \pm 1 \mathrm{~cm} / \mathrm{yr}$, the NFB would have taken about 14 m.y. to open, instead of 8-12 m.y. Therefore, our analysis indicates a decrease from a higher convergence rate to $13.2 \mathrm{~cm} / \mathrm{yr}$ or less at the central NHIA whether it occurred during the past $1.42 \mathrm{Ma}$ or earlier.

We can place some reasonable limits (see shaded box, Fig. 10) on the timing of this rate change if it occurred as stated in our above list of assumptions. Because the A/P relative rate at Espiritu Santo Island is $8.8 \mathrm{~cm} / \mathrm{yr}$ (DeMets et al., 1990), we propose this as the minimum reasonable rate. Arbitrarily, we choose $25 \mathrm{~cm} / \mathrm{yr}$ as an upper limit. With these additional assumptions, any major change in convergence rate conforming to our assumptions must have occurred sometime between 1.1 and $0.2 \mathrm{Ma}$ (Fig. 10).

Chase (1971), Falvey (1975), and Malahoff et al. (1982) estimated rapid rates of NFB opening as high as $9.6 \mathrm{~cm} / \mathrm{yr}$. Several recent papers propose that spreading centers forming a triple junction south of the Hazel Holme Fracture Zone in the NFB have jumped and reorganized at about 0.5-1.0 Ma and at 1.2 Ma (Auzende et al., 1988; Tanahashi et al., 1991). It seems likely that this has produced highly variable opening rates and directions for the NFB. However, we can not constrain the timing of changes of convergence rates and NFB opening sufficiently to correlate events.

Another possible cause for a decrease in convergence rate at the central NHIA could be related to the collision of the DEZ and compression of the Espiritu Santo-Malakula region eastward into the NFB. This is supported by folds in young seafloor sediments east of Maewo and Pentecost, seafloor expression of a possible thrust fault from GLORIA data (Price et al., 1993), and earthquakes having reverse-fault focal mechanisms beneath these islands (Collot et al., 1985; Louat and Pelletier, 1989; Greene et al., this volume). There is no quantitative estimate of the amount of such deformation at the central NHIA. However, if we assume that the convergence rate changed from 17.2 to $13.2 \mathrm{~cm} / \mathrm{yr}$, then the boundary between the central NHIA and NFB would have had to accommodate $15.72 \mathrm{~km}$ of shortening since $0.393 \mathrm{Ma}$. This appears to be an unacceptably large amount because the plate boundary west of Malakula and Espiritu Santo Islands would have to be offset to the east by this amount. Perhaps $1 \mathrm{~cm} / \mathrm{yr}$ of shortening as suggested by Louat and Pelletier (1989) is more realistic, but it would account for a rate change from only 14.2 to $13.2 \mathrm{~cm} / \mathrm{yr}$. In any case, shortening across the central NHIA must be a factor in the net convergence rate.

However, we are confident that the mean convergence rate of 13.2 $\mathrm{cm} / \mathrm{yr}$ since $0.393 \mathrm{Ma}$ indicates that opening of the NFB continues to contribute several centimeters per year to the net convergence rate at the central NHIA. Models of contemporary microplate motions in the NFB should account for this rate of relative motion between the central NHIA and P plate. This study also constrains convergence rates at the central NHIA on a time scale not addressed by GPS measurements or plate tectonic analyses (e.g., Minster and Jordan, 1978; DeMets et al., 1990).

An important question is whether geodynamic processes require that the net average opening rate of the NFB is preserved regardless of the orientation of the spreading centers or whether spreading rates slow or accelerate as spreading centers change location. Results from BG indicate that the NFB opening rate does change on the $10^{5}$ - to $10^{6}$-yr time scale.
Convergence rates of 13.2 to $17.2 \mathrm{~cm} / \mathrm{yr}$ during the past $1.42 \mathrm{~m} . \mathrm{y}$. show that studies assuming only the A/P relative motion at the NHIA greatly underestimate the actual A/NHIA convergence rate. The direction of A/NHIA convergence of about $076 \pm 11^{\circ}$ (Pascal et al. 1978; Isacks et al., 1981) based on focal mechanisms, however, is independent and remains valid. The estimates of the percentage of aseismic slip for arc segments of the central NHIA should probably be increased by $50 \%$ to $100 \%$ (Taylor et al., 1990).

Migration rates of the DEZ relative to the central NHIA and timing for the resulting tectonic effects, including possible seamount collisions with the arc, should be appropriately increased (e.g., Collot et al., 1985; Collot and Fisher, 1989; Collot and Fisher, 1991; Fisher et al., 1991). For example, if the arc trend is $340^{\circ}$, the DEZ is east-west, the convergence direction is $076^{\circ}$, and the A/NHIA convergence rate is $8.8 \mathrm{~cm} / \mathrm{yr}$, then the northward migration rate for the DEZ along the arc is $2 \mathrm{~cm} / \mathrm{yr}$. For a convergence rate of $17.2 \mathrm{~cm} / \mathrm{yr}$, the migration rate would be $4.1 \mathrm{~cm} / \mathrm{yr}$. At the convergence rate of $8.8 \mathrm{~cm} / \mathrm{yr}$, the northern edge of the DEZ would have migrated from the southern limit of Espiritu Santo Island to its present position in about $3.5 \mathrm{~m}$.y. At migration rates of $4.1 \mathrm{~cm} / \mathrm{yr}$, the time required would be $1.8 \mathrm{~m} . \mathrm{y}$. Over the past 8-12 m.y. an average A/NHIA convergence rate of 14 to $16.5 \mathrm{~cm} / \mathrm{yr}$ is required by opening of the NFB, so that an average northward migration rate of the DEZ on the order of 3.2 to $4 \mathrm{~cm} / \mathrm{yr}$ is likely. In general, these more rapid convergence and DEZ migration rates support a more recent uplift history for the central NHIA frontal arc as suggested by Taylor (1992).

The earlier Oligocene to Pliocene hiatuses in carbonate deposition inferred from strontium ages are subject to limited interpretation because of the poor sample recovery. However, the hiatuses from 17.29 (429.67 mbsf) to $10.68 \mathrm{Ma}(410.31 \mathrm{mbsf})$ and from 10.68 (410.31 mbsf) to 1.66 (391.11 mbsf) Ma are particularly notable. There was only about $30 \mathrm{~m}$ of net carbonate deposition in $15.63 \mathrm{~m} . \mathrm{y}$. This appears to correspond to a hiatus reported for the time interval from about middle Miocene to Pliocene at DSDP Site 286 located in the North Loyalty Basin, about $70 \mathrm{~km}$ southwest of Site 831 (Andrews, Packham, et al., 1975). The hiatus ends at Site 286 as volcanic-ash-rich sediment derived from the NHIA began to become significant. Maillet et al. (1983) suggest that this hiatus may be related to middle Miocene to early Pleistocene extensional tectonics on the New Caledonia Ridge (Coudray, 1977). The DEZ appears to be continuous with the New Caledonia Ridge and may also have undergone some tectonic dislocations. It is also possible that the hiatuses at Site 831 and Site 286 could be related to thermal uplift or resetting of the thermal age of the North Loyalty Basin and DEZ area corresponding to late Miocene volcanism on the Loyalty Islands dated at about $10 \mathrm{Ma}$ on Mare Island (Baubron et al., 1976). A thermal event could have caused emergence of BG and a hiatus in carbonate deposition.

\section{CONCLUSIONS}

The chronostratigraphy of BG indicates that convergence rates at the central NHIA have been $13.2 \mathrm{~cm} / \mathrm{yr}$ from $0.393-0 \mathrm{Ma}$ and that the convergence rate was $17.2 \mathrm{~cm} / \mathrm{yr}$ from about 1.42 to $0.393 \mathrm{Ma}$. The overall average convergence rate from 1.42 to $0 \mathrm{Ma}$ has been 16.1 $\mathrm{cm} / \mathrm{yr}$. The accuracy of the more recent rate of $13.2 \mathrm{~cm} / \mathrm{yr}$ is strongly supported by concordant uranium-series ages and the steep slope of the trajectory of the downgoing plate where $\mathrm{BG}$ re-submerged. $\mathrm{Be}$ cause the relative convergence rate between the $\mathrm{A}$ and $\mathrm{P}$ plates is 8.8 $\mathrm{cm} / \mathrm{yr}$, opening of the NFB is probably contributing about $4.4 \mathrm{~cm} / \mathrm{yr}$ to the net convergence rate at the central NHIA. The $17.2 \mathrm{~cm} / \mathrm{yr}$ convergence rate from 1.42 to 0.393 Ma may be less accurate because of relatively large errors on the strontium isotope age of $1.42 \mathrm{Ma}$, the gentle slope of the lithospheric trajectory as BG began to ascend the outer rise, uncertainties about paleosea levels, and other possible sources of error. However, relative $\mathrm{A} / \mathrm{P}$ rates and the opening history of the NFB require that the convergence rate at the central NHIA has averaged $14-16 \mathrm{~cm} / \mathrm{yr}$ since $8-12 \mathrm{Ma}$. The rate of $13.2 \mathrm{~cm} / \mathrm{yr}$ since 
0.393 Ma strongly supports a decrease in the contribution of the NFB opening to the convergence rate at NHIA. The change of convergence rates that we propose most likely would have occurred between 1.1 and $0.2 \mathrm{Ma}$. This time range corresponds to significant reorganizations of spreading centers, including ridge jumps, near the ridgeridge-ridge triple junction in the NFB. Despite the limitations on the data from Site 831, they place valuable constraints on the possible range of convergence rates that could have occurred since $1.42 \mathrm{Ma}$ at the central NHIA. We look forward to comparing these results with forthcoming GPS results giving contemporary convergence rates across the southern New Hebrides Trench and the NFB.

\section{ACKNOWLEDGMENTS}

We thank the crew and technicians aboard the SEDCO BP 471 (JOIDES Resolution) and our fellow scientists on Leg 134 for all of their support in making the samples and data available to us. We particularly wish to acknowledge the outstanding performance of staff scientist Laura Stokking and the co-chief scientists Jean-Yves Collot and H. Gary Greene. Cliff Frohlich contributed valuable suggestions for analyzing the convergence rates and improving the manuscript. This research was funded by TAMRF PO \#20473, and TAMRF Grant \#20522 to Taylor, and TAMRF PO \#20469 and TAMRF Grant \#20523 to Quinn from JOI-USSAC through the Texas A\&M Research Foundation, and by NSF Grants EAR-8904987 to Taylor and EAR 8904705 to Edwards. The University of Texas at Austin Institute for Geophysics contribution number 982.

\section{REFERENCES*}

Andrews, J.E., Packham, G., et al., 1975. Init. Repts. DSDP, 30: Washington (U.S. Govt. Printing Office).

Auzende, J.-M., Lafoy, Y., and Marsset, B., 1988. Recent geodynamic evolution of the north Fiji Basin (southwest Pacific). Geology, 16:925-929.

Baubron, J.C., Guillon, J.H., and Recy, J., 1976. Geochronologie par la methode $\mathrm{K} / \mathrm{Ar}$ du substrat volcanique de l'ile Mare, archipel des Loyaute (Sud-Ouest Pacifique). Bull. Bur. Rech. Geol. Min. Sect. 2: Geol. Appl., $4: 165-175$.

Bevis, M.G., Schutz, B.E., Taylor, F.W., Stowell, J., Perin, B., and Recy, J., 1991. Crustal motions observed near the Tonga trench (1988-1990). Eos, $72: 115$.

Chase, C.G., 1971. Tectonic history of the Fiji plateau. Geol. Soc. Am. Bull., 82:3087-3110.

Collot, J.-Y., Daniel, J., and Burne, R.V., 1985. Recent tectonics associated with the subduction/collision of the d'Entrecasteaux zone in the central New Hebrides. Tectonophysics, 112:325-356.

Collot, J.-Y., and Fisher, M.A., 1989. Formation of forearc basins by collision between seamounts and accretionary wedges: an example from the New Hebrides subduction zone. Geology, 17:930-933.

— 1991. The collision zone between the North d'Entrecasteaux Ridge and the New Hebrides Island Arc. Part 1: Seabeam morphology and shallow structure. J. Geophys. Res., 96:4457-4478.

Collot, J.-Y., Greene, H.G., Stokking, L.B., et al., 1992. Proc. ODP, Init. Repts., 134: College Station, TX (Ocean Drilling Program).

Collot, J.-Y., Lallemand, S., Pelletier, B., Eissen, J.-P., Glaçon, G., Fisher, M.A., Greene, H.G., Boulin, J., Daniel, J., and Monzier, M., 1992. Geology of the d'Entrecasteaux-New Hebrides island arc collision: results from a deep-sea submersible survey. Tectonophysics, 212:213-241.

Coudray, J., 1977. The main events of the sedimentary and structural history of New Caledonia from the Oligocene to the present day. In Symp. on Geodynamics in South-West Pacific, Noumea 1976: Paris (Editions Technip), 217-228.

de Bievre, P., Lauer, K.J., Le Duigon, Y., Moret, H., Muschenborn, G., Spaepen, J., Spernol, A., Vaninbroukx, R., and Verdingh, V., 1971. The half-life of U-234. In Hurrell, M.L. (Ed.), Proc. Intl. Conf. Chem. Nucl.

\footnotetext{
- Abbreviations for names of organizations and publications in ODP reference lists follow the style given in Chemical Abstracts Service Source Index (published by American Chemical Society).
}

Data, Measurement and Applications, Canterbury: London (Inst. Civil Engineers), 221-225.

Demets, C., Gordon, R.G., Argus, D.F., and Stein, S., 1990. Current plate motions. Geophys. J. Int., 101:425-478.

DePaolo, D.J., and Ingram, B.L., 1985. High-resolution stratigraphy with strontium isotopes. Science, 227:938-940.

Dubois, J., Deplus, C., Diament, M., Daniel, J., and Collot, J.-Y., 1988. Subduction of the Bougainville seamount (Vanuatu): mechanical and geodynamic implications. Tectonophysics, 149:111-119.

Dubois, J., Launay, J., and Recy, J., 1974. Uplift movements in New Caledonia-Loyalty Islands area and their plate tectonics interpretation. Tectonophysics, 24:133-150.

Dubois, J., Launay, J., Recy, J., and Marshall, J., 1977. New Hebrides, trench: subduction rate from associated lithospheric bulge. Can. J. Earth Sci., 14:250-2550.

Edwards, R.L., Beck, J.W., Burr, G.S., Donahue, D.J., Chappell, J.M.A., Bloom, A.L., Druffel, E.R.M., and Taylor, F.W., 1993. A large drop in atmospheric ${ }^{14} \mathrm{C} /{ }^{12} \mathrm{C}$ and reduced melting in the Younger Dryas, documented with ${ }^{230}$ Th ages of coral. Science, 260:962-968.

Edwards, R.L., Chen, J.H., and Wasserburg, G.J., $1987 .{ }^{238} \mathrm{U}^{234} \mathrm{U}^{230} \mathrm{Th}-$ ${ }^{232} \mathrm{Th}$ systematics and the precise measurement of time over the past 500,000 years. Earth Planet Sci Lett., 81:175-192.

Edwards, R.L., Gallup, C.D., Taylor, F.W., Quinn, T.M., and ODP Leg 134 Scientific Party, 1991. ${ }^{230} \mathrm{Th} /{ }^{238} \mathrm{U}$ and ${ }^{234} \mathrm{U} /{ }^{238} \mathrm{U}$ in submarine corals: evidence for diagenetic leaching of ${ }^{234} \mathrm{U}$. Eos, 72:535.

Edwards, R.L., Taylor, F.W., Chen, J.H., and Wasserburg, G.J., 1988. High precision thorium-230 dating of corals using thermal ionization mass spectrometry: applications to paleoseismology. In Crone, A.J., and Omdahl, E.M. (Eds.), Directions in Paleoseismology. Open-File Rep.-U.S. Geol. Surv., 87-673:30-38.

Eissen, J.-P., Lefevre, C., Maillet, P., Morvan, G., and Nohara, M., 1991. Petrology and geochemistry of the central North Fiji Basin spreading centre (Southwest Pacific) between $16^{\circ} \mathrm{S}$ and $22^{\circ} \mathrm{S}$. Mar. Geol., 98:201-239.

Falvey, D.A., 1975. Arc reversals, and a tectonic model for the North Fiji Basin. Australas. Soc. Explor. Geophys. Bull., 6:47-49.

, 1978. Analysis of paleomagnetic data from the New Hebrides. Australas. Soc. Explor. Geophys. Bull., 9:117-123.

Fisher, M.A., Collot, J.-Y., and Geist, E.L., 1991. The collision zone between the North d'Entrecasteaux Ridge and the New Hebrides Island Arc. Part 2: structure from multichannel seismic data. J. Geophys. Res., 96:4479-4495.

Isacks, B.L., Cardwell, R.K., Chatelain, J.L., Barazangi, M., Marthelot, J.-M., Chinn, D., and Louat, R., 1981. Seismicity and tectonics of the central New Hebrides island arc. In Simpson, D.W., and Richards, P.G. (Eds.), Earthquake Prediction: An International Review. Am. Geophys. Union, Maurice Ewing Ser., 4:93-116.

Jaffey, A.H., Flynn, K.F., Glendenin, L.W., Bentley, W.C., and Essling, A.M., 1971. Precision measurements of half-lives and specific activities of U-235 and U-238. Phys. Rev., C4:1889-1906.

Louat, R., and Pelletier, B., 1989. Seismotectonics and present-day relative plate motions in the New Hebrides-North Fiji basin region. Tectonophysics, 167:41-55.

Lounsbury, M., and Durham, R.W., 1971. The alpha half-life of U-234. In Hurrell, M.L. (Ed.), Proc. Intl. Conf. Chem. Nucl. Data, Measurement and Applications, Canterbury. Inst. Civ. Eng., 215-219.

Maillet, P.M., Monzier, M., Selo, M., and Storzer, D., 1983. The d'Entrecasteaux zone (southwest Pacific): a petrological and geochronological reappraisal. Mar. Geol., 53:179-197.

Malahoff, A., Feden, R.H., and Fleming, H.S., 1982. Magnetic anomaly and tectonic fabric of marginal basins north of New Zealand. J. Geophys. Res., $87: 4109-4125$.

Meadows, J.W., Armani, R.J., Callis, E.L., and Essling, A.M., 1980. Half-life of Th-230. Phys. Rev. C, 22:750-754.

Minster, J.B., and Jordan, T.H., 1978. Present-day plate motions. J. Geophys. Res., 83:5331-5354.

Montaggioni, L., Butterlin, J., Glaçon, G., Collot, J.-Y., Monzier, M., Pelletier, B., Boulin, J., Lallemand, S., Daniel, J., Faure, G., Lauriat-Rage, A., Vénec-Peyré, M.-T., Blondeau, A., Lozouet, P., Vacelet, J., and Babinot, J.-F., 1991. Signification géodynamique des calcaires de plate-forme en cours de subduction sous l'Arc des Nouvelles-Hébrides (sud-ouest de l'Océan Pacifique). C. R. Acad. Sci. Ser. 2, 313:661-668.

Neumann, A.C., and Macintyre, I., 1985. Reef response to sea level rise: keep-up, catch-up, or give-up. Proc. Sth Int. Coral Reef Symp., 3:105-108.

Parsons, B., and Sclater, J.G., 1977. An analysis of the variation of ocean floor bathymetry and heat flow with age. J. Geophys. Res., 82:803-827. 
Pascal, G., Isacks, B.L., Barazangi, M., and Dubois, J., 1978. Precise relocations of earthquakes, and seismotectonics of the New Hebrides island arc. J. Geophys. Res., 83:4957-4973.

Price, R.C., Maillet, P., and Johnson, D.P., 1993. Interpretation of GLnRIA side-scan sonar imagery for the Coriolis Troughs of the New Hebrides backarc. Geo-Mar. Lett., 13:71-81.

Quinn, T.M., 1991. Comment and reply on "Post-Miocene diagenetic and eustatic history of Enewetak Atoll: model and data comparison." Geology, 19:957-958.

Quinn, T.M., and Matthews, R.K., 1990. Post-Miocene diagenetic and eustatic history of Enewetak Atoll: model and data comparison. Geology, 18:942-945.

Ruff, L., and Kanamori, H., 1980. Seismicity and the subduction process. Phys. Earth Planet. Inter, 23:240-252.

Sykes, L.R., and Quittmeyer, R.C., 1981. Repeat times of great earthquakes along simple plate boundaries. In Simpson, D.W., and Richards, P.G. (Eds.), Earthquake Prediction. Am. Geophys. Union, Maurice Ewing Ser., 4:217-247.

Tanahashi, M., Kisimoto, K., Joshima, M., Lafoy, Y., Honza, E., and Auzende, J. M., 1991. Geological structure of the central spreading system, North Fiji Basin. Mar. Geol., 98:187-200.
Taylor, F.W., 1992. Quaternary vertical tectonics of the central New Hebrides Island Arc. In Collot, J.-Y., Greene, H.G., Stokking, L.B., et al., Proc. ODP, Init. Repts., 134: College Station, TX (Ocean Drilling Program), 33-42.

Taylor, F.W., Edwards, R.L., Wasserburg, G.J., and Frohlich, C., 1990. Seismic recurrence intervals and timing of aseismic subduction inferred from emerged corals and reefs of the central Vanuatu (New Hebrides) frontal arc. J. Geophys. Res., 95:393-408.

Weissel, J.K., Watts, A.B., and Lapouille, A., 1982. Evidence for late Paleocene to late Eocene sea floor in the southern New Hebrides Basin. Tectonophysics, 87:243-251.

Wheeler, C.W., and Aharon, P., 1991. Mid-oceanic carbonate platforms as oceanic dipsticks: examples from the Pacific. Coral Reefs, 10:101-106.

Date of initial receipt: 14 April 1992

Date of acceptance: 30 March 1993

Ms 134SR-003 